\title{
Skin Squamous Cell Carcinoma or Other Skin Carcinomas pT2 TNM Finding v7
}

National Cancer Institute

\section{Source}

National Cancer Institute. Skin Squamous Cell Carcinoma or Other Skin Carcinomas pT 2

TNM Finding v7. NCI Thesaurus. Code C88479.

Skin squamous cell carcinoma or other skin carcinomas with a tumor size greater than 2 $\mathrm{cm}$ in greatest dimension or tumor of any size with two or more high-risk features. Highrisk features for the primary tumor staging are defined as follows: depth/invasion of more than $2 \mathrm{~mm}$ thickness; Clark level equal to or greater than IV; and perineural invasion. Anatomic location: primary site ear and primary site non-hair-bearing lip. Differentiation: poorly differentiated or undifferentiated. (from AJCC 7th Ed.) 